\title{
Orem's Nurse Coaching Approach on Interdialytic Weight Gain Changes and Phlebitis in Chronic Kidney Disease Client with Hemodialysis
}

\author{
Shobirun", Supriyadi, Elisa, Sri Utami Dwiningsih, Heru Supriyatno, Sawab \\ Politeknik Kesehatan, Kemenkes Semarang, Indonesia
}

*Corresponding Author: Shobirun, Nursing Department, Politeknik Kesehatan, Kemenkes Semarang, Jl. Tirto Agung Pedalangan, Banyumanik, Indonesia, Email: mshobirun@yahoo.com

\begin{abstract}
:
Background: Coaching is a learning model applied by nurses in educating sufferers in hopes to change of Interdialytic Weight Gain (IDWG) and phlebitis in the client of chronic kidney disease with hemodialysis.

The Objective: This study aims to determine the effect of the application of Orem's learning model with coaching approach to IDGW changes and phlebitis in the client of chronic kidney disease (CKD) with hemodialysis.
\end{abstract}

Method: This research used a quasi-experimental design to forty respondents with no equivalent control group design and done in time series. CKD patients were given OREM's method of learning by coaching method using teaching approach, guiding, and environment and health education with the information provided to the patient to change patient behavior in limiting daily fluid intake.

Result: Friedman test results in the coaching group showed no IDWG relationship before coaching treatment until the seventh coaching treatment and no connection before the non-coaching treatment from before treatment until the seventh treatment. The dependent-t test showed no means difference of IDWG between the coaching group and the non-coaching group and the initial IDWG in each cluster. Mann Whitney test results showed no difference in early signs of phlebitis between coaching groups and non-coaching groups.

Conclusion: Orem's learning model with coaching approach found that there was a difference of urea level in coaching group before and after coaching but no difference of pre and post urea level in the non-coaching group. There was no difference in mean creatinine levels before and after treatment between coaching groups and non-coaching groups.

Keywords: Coaching, Interdialytic weight gain (IDWG), phlebitis, Chronic Kidney Disease (CKD), hemodialysis.

\section{INTRODUCTION}

Chronic Kidney Disease (CKD) is a failure of kidney function to maintain metabolism as well as fluid and electrolyte balance due to progressive destruction of a renal structure with the manifestation of metabolic (urethic) toxic buildup in the blood (Muttaqin \& Sari 2011). Patients with CKD are usually given hemodialysis.

According to Suharyanto and Madjid (2009), the purpose of hemodialysis is to remove the toxic nitrogen substances from the blood and remove excess water from the body. A common complication in patients undergoing hemo dialysis is weight gain between two-time hemodialysis known as Inter Dialytic Weight
Gain (IDWG). The increased IDWG can lead to client problems such as hypertension, Interdialytic hypotension, peripheral edema, ascites, pleural effusion, heart failure and decreased the quality of life (Pace, 2007). Also, Levey et al. (2003) explain that IDWG increases are caused by various internal factors such as age, sex, education level, thirst, stress, self-efficacy, and external factors such as family and social support and the amount of fluid intake.

In Indonesia, patients undergoing hemodialysis also experience an increase in IDWG as the study conducted by Riyanto (2011) showed that the distribution of weight gain between two hemodialyses in the mild category was $11.8 \%$, 
Orem's Nurse Coaching Approach on Interdialytic Weight Gain Changes and Phlebitis in Chronic Kidney Disease Client with Hemodialysis

the means group was $64.5 \%$ and hazard categories of $23.7 \%$. The study was also supported with a case study conducted by Lolyta (2012) showing that the majority of respondents experienced a weight gain of more than $5 \%$ of dry weight as much as 25 respondents $(52.1 \%)$ and that no more than $5 \%$ of dry body weight 23 respondents (47.1\%).

Nurses as health workers have a role in the provision of nursing care and as well as educators who are responsible for improving the knowledge and compliance of patients and families about the restriction of fluid intake for patients with CKD. The nurse can provide education on the rules used to determine the amount of fluid intake by determining the amount of urine released during the last 24 hours + $500 \mathrm{ml}$ (Suharyanto \& Madjid, 2009). Nurses' education on fluid intake restriction has not shown maximum results on adherence level and the quality of life of chronic renal failure patients with hemodialysis in hospitals of Semarang city, Indonesia. Orem's Learning Model with a coaching approach in nursing services is expected to be a partnership approach method with the aim of exploring the hidden potentials that coaches possess to address various problems. Coaching is a learning model applied by nurses in educating which includes teaching method, guiding, and environment (Alligood, 2004).) In hopes can imply to change of Interdialytic Weight Gain (IDWG) and phlebitis in the client of chronic kidney disease (CKD) with hemodialysis.

\section{MATerials AND Methods}

This study was an experimental design with no equivalent control group and completed in time series horizon. The population in this study were all CKD patients undergoing hemodialysis therapy at Semarang City Hospital. The number of samples in this study was 40 people divided into two groups. One group was treated with Orem's coaching method while another group consisted of 20 respondents with no coaching provided.

The data collection tools were:

1. Orem's learning model with coaching method.

2. Observation sheets containing bio data, review the form of edema evaluation form, IDWG (weight), and signs of phlebitis.
3. Questionnaire characteristic of respondents which include age, sex, education and the length undergoing hemodialysis.

Friedman test and Mann Whitney test were used to see if there was any difference between those who underwent coaching and those who did not. Paired t-test was used to examine whether there was an average difference of each treatment stage.

\section{RESULT AND DISCUSSION}

\subsection{Result}

Characteristics of respondents are presented in the following tables.

Table1. Respondents' characteristic

\begin{tabular}{|c|c|c|c|c|c|}
\hline No & $\begin{array}{l}\text { Characteristics } \\
\text { of Respondents }\end{array}$ & $\begin{array}{l}\text { Coaching } \\
\text { (f) }\end{array}$ & $\%$ & $\begin{array}{c}\text { Non } \\
\text { Coaching } \\
\text { (f) }\end{array}$ & $\%$ \\
\hline 1. & 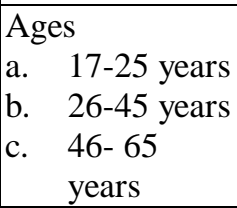 & $\begin{array}{c}1 \\
13 \\
6\end{array}$ & $\begin{array}{c}5 \\
65 \\
30\end{array}$ & $\begin{array}{c}1 \\
7 \\
12\end{array}$ & $\begin{array}{c}5 \\
35 \\
60\end{array}$ \\
\hline & Total & 20 & 100 & 20 & 100 \\
\hline 2. & $\begin{array}{l}\text { Genders } \\
\text { a. Male } \\
\text { b. b. Female }\end{array}$ & $\begin{array}{c}8 \\
12 \\
\end{array}$ & $\begin{array}{l}40 \\
60 \\
\end{array}$ & $\begin{array}{l}10 \\
10 \\
\end{array}$ & $\begin{array}{l}50 \\
50 \\
\end{array}$ \\
\hline & Total & 20 & 100 & 20 & 100 \\
\hline 3 & \begin{tabular}{|ll}
\multicolumn{2}{|l}{ Education } \\
a. & not \\
& completed \\
& elementary \\
b. & Elementary \\
c. & Secondary \\
d. & Junior High \\
e. & Degree
\end{tabular} & $\begin{array}{c}1 \\
2 \\
5 \\
11 \\
1\end{array}$ & $\begin{array}{c}5 \\
10 \\
25 \\
55 \\
5\end{array}$ & $\begin{array}{l}3 \\
2 \\
5 \\
8 \\
2\end{array}$ & $\begin{array}{l}15 \\
10 \\
25 \\
40 \\
10\end{array}$ \\
\hline & Total & 20 & 100 & 20 & 100 \\
\hline 3. & $\begin{array}{l}\text { The length of } \\
\text { illness } \\
\text { a. <1-year } \\
\text { b. } 1-3 \text { years } \\
\text { c. c. }>3 \text { years }\end{array}$ & $\begin{array}{l}8 \\
5 \\
7\end{array}$ & $\begin{array}{l}40 \\
25 \\
35\end{array}$ & $\begin{array}{c}10 \\
6 \\
4\end{array}$ & $\begin{array}{l}50 \\
30 \\
20\end{array}$ \\
\hline & Total & 20 & 100 & 20 & 100 \\
\hline 4. & \begin{tabular}{ll}
\multicolumn{2}{l}{ Stadium : } \\
a. & I \\
b. & b.II \\
c. & c.III \\
d. & d.IV \\
e. & e.V
\end{tabular} & $\begin{array}{c}0 \\
0 \\
0 \\
0 \\
20\end{array}$ & $\begin{array}{c}0 \\
0 \\
0 \\
0 \\
100\end{array}$ & $\begin{array}{c}0 \\
0 \\
0 \\
0 \\
20\end{array}$ & $\begin{array}{c}0 \\
0 \\
0 \\
0 \\
100\end{array}$ \\
\hline & Total & 20 & 100 & 20 & 100 \\
\hline
\end{tabular}

Table 1 showed that in coaching group there were 13 adults $(65 \%)$ and the remaining 6 (30\%) were older adults. In the non-coaching group, there were seven adults (35\%), and the remaining 12 people $(60 \%)$ were older adults. 
Orem's Nurse Coaching Approach on Interdialytic Weight Gain Changes and Phlebitis in Chronic Kidney Disease Client with Hemodialysis

Most of the respondents were female (12\%) $(60 \%)$ in the coaching group. While in the noncoaching group as much. The education of respondent of coaching group is mostly, 11 people (55\%) are SMA while in non-coaching group 8 (40\%) have high school education. Period of illness is less than one year in group coaching $8(40 \%)$ whereas in non-coaching group 10 people $(50 \%)$. All respondents in the coaching group and the non-coaching group had CKD stage V disease (100\%).

Table2. Interdialytic Weight Gain (IDWG)

\begin{tabular}{|c|c|c|c|c|c|c|}
\hline & \multicolumn{3}{|c|}{$\begin{array}{c}\text { Coaching Group } \\
(\mathrm{N}=20)\end{array}$} & \multicolumn{3}{c|}{$\begin{array}{c}\text { Non-Coaching Group } \\
(\mathrm{N}=20)\end{array}$} \\
\hline & Min & Max & Mean & Min & Max & Mean \\
\hline IDWG: & & & & & & \\
\hline 1st & .00 & 3.20 & .7150 & .00 & 8.80 & 1.7500 \\
\hline 2nd & .00 & 6.20 & 1.4100 & .00 & 50.00 & 4.1600 \\
\hline 3rd & .00 & 3.50 & .8650 & .00 & 33.30 & 3.5750 \\
\hline 4th & .00 & 1.80 & .4500 & .00 & 25.00 & 2.7750 \\
\hline 5th & .00 & 2.70 & .8750 & .00 & 20.00 & 3.1700 \\
\hline 6th & .00 & 4.20 & 1.1050 & .00 & 16.70 & 2.5550 \\
\hline 7th & .00 & 2.40 & .3750 & .00 & 14.30 & 2.1300 \\
\hline
\end{tabular}

Table 2 showed that the frequency of IDWG group coaching on the first treatment was 0.7150 and to the seventh treatment reached 0.3750 . In the non-coaching group the rate of IDWG in the first treatment was as much as 1.7500 and to the seventh treatment was as much as 2.1300. This figure indicated that the IDWG in the coaching group decreased while in the non-coaching group increased.

Table3. Friedman test on IDWG coaching and noncoaching groups

\begin{tabular}{|c|c|c|c|c|}
\hline \multirow{2}{*}{} & \multicolumn{2}{|c|}{$\begin{array}{c}\text { Coaching } \\
\text { Group }(\mathrm{N}=20)\end{array}$} & \multicolumn{2}{c|}{$\begin{array}{c}\text { Non-Coaching } \\
\text { Group }(\mathrm{N}=20)\end{array}$} \\
\cline { 2 - 6 } & $\begin{array}{c}\text { Mean } \\
\text { Rank }\end{array}$ & $\begin{array}{c}P- \\
\text { Value }\end{array}$ & $\begin{array}{c}\text { Mean } \\
\text { Rank }\end{array}$ & $\begin{array}{c}P- \\
\text { Value }\end{array}$ \\
\hline $1^{\text {st }}$ IDWG & 3.80 & & 3.72 & \\
\hline $2^{\text {2d }}$ IDWG & 4.78 & 0.043 & 4.10 & .683 \\
\hline $3^{\text {rd }}$ IDWG & 4.02 & & 4.62 & \\
\hline $4^{\text {th }}$ IDWG & 3.40 & & 3.62 & \\
\hline $5^{\text {th }}$ IDWG & 4.20 & & 4.28 & \\
\hline $6^{\text {th }}$ IDWG & 4.70 & & 4.05 & \\
\hline $7^{\text {th }}$ IDWG & 3.10 & & 3.60 & \\
\hline
\end{tabular}

Table 3 showed that the average IDWG in coaching and the non-coaching group from Friedman test result obtained the p-value of 0.043 and 0.683 . Thus, it is concluded that there is an IDWG relationship before the coaching treatment until it is given the seventh treatment and there is no connection before the non-coaching treatment from before treatment until it is given the seventh treatment.
Table4. Paired wise comparison test of IDWG coaching group

\begin{tabular}{|l|c|}
\hline & $P$-Value \\
\hline IDWG the first vs. IDWG the second & .055 \\
\hline IDWG the first vs. IDWG the third & .753 \\
\hline IDWG the first vs. IDWG the fourth & .382 \\
\hline IDWG the first vs. IDWG the fifth & .362 \\
\hline IDWG the first vs. IDWG the sixth & .196 \\
\hline IDWG the first vs. IDWG the seventh & .239 \\
\hline IDWG the second vs. IDWG the third & .315 \\
\hline IDWG the second vs. IDWG the fourth & .005 \\
\hline IDWG the second vs. IDWG the fifth & .352 \\
\hline IDWG the second vs. IDWG the sixth & .615 \\
\hline IDWG the second vs IDWG the seventh & .008 \\
\hline IDWG the third vs IDWG the fourth & .103 \\
\hline IDWG the third vs IDWG the fifth & .888 \\
\hline IDWG the third vs IDWG the sixth & .553 \\
\hline IDWG the third vs IDWG the seventh & .168 \\
\hline IDWG the fourth vs IDWG the fifth & .099 \\
\hline IDWG the fourth vs IDWG the sixth & .035 \\
\hline IDWG the fourth vs IDWG the seventh & .644 \\
\hline IDWG the fifth vs IDWG the sixth & .506 \\
\hline IDWG the fifth vs IDWG the seventh & .084 \\
\hline IDWG the sixth vs IDWG the seventh & .014 \\
\hline
\end{tabular}

Table 4 showed that in the first IDWG comparing coaching group vs. the seventh IDWG obtained $\mathrm{p}$ value 0.239 . Thus, it is concluded no change in the first IDWG vs. the seventh IDWG. On the sixth IDWG comparison vs. IDWG the seventh, the p value is 0.014 . This way, it is concluded there is a difference of sixth IDWG vs. IDWG the seventh.

Table5. Dependent $t$ - test means on IDWG between Coaching and Non-Coaching Groups

\begin{tabular}{|c|c|c|c|c|}
\hline & Groups & $\mathrm{N}$ & $\begin{array}{l}\text { Mean } \\
\text { Rank }\end{array}$ & $\begin{array}{l}P \text { - } \\
\text { Value }\end{array}$ \\
\hline \multirow{3}{*}{$\begin{array}{l}1^{\text {st }} \\
\text { IDWG }\end{array}$} & Coaching & 20 & 17.95 & \multirow[t]{3}{*}{.156} \\
\hline & Non-Coaching & 20 & 23.05 & \\
\hline & Total & 40 & & \\
\hline \multirow{3}{*}{$\begin{array}{l}2^{\text {nd }} \\
\text { IDWG }\end{array}$} & Coaching & 20 & 18.90 & \multirow[t]{3}{*}{.380} \\
\hline & Non-Coaching & 20 & 22.10 & \\
\hline & Total & 40 & & \\
\hline \multirow{3}{*}{$\begin{array}{l}3^{\text {rd }} \\
\text { IDWG }\end{array}$} & Coaching & 20 & 16.18 & \multirow[t]{3}{*}{.016} \\
\hline & Non-Coaching & 20 & 24.82 & \\
\hline & Total & 40 & & \\
\hline \multirow{3}{*}{$\begin{array}{l}4^{\text {th }} \\
\text { IDWG }\end{array}$} & Coaching & 20 & 17.05 & \multirow[t]{3}{*}{.046} \\
\hline & Non-Coaching & 20 & 23.95 & \\
\hline & Total & 40 & & \\
\hline \multirow{3}{*}{$\begin{array}{l}5^{\text {th }} \\
\text { IDWG }\end{array}$} & Coaching & 20 & 17.12 & \multirow[t]{3}{*}{.063} \\
\hline & Non-Coaching & 20 & 23.88 & \\
\hline & Total & 40 & & \\
\hline \multirow{3}{*}{$\begin{array}{l}6^{\text {th }} \\
\text { IDWG }\end{array}$} & Coaching & 20 & 17.95 & \multirow[t]{3}{*}{.162} \\
\hline & Non-Coaching & 20 & 23.05 & \\
\hline & Total & 40 & & \\
\hline \multirow{3}{*}{$\begin{array}{l}7^{\text {th }} \\
\text { IDWG }\end{array}$} & Coaching & 20 & 16.02 & \multirow[t]{3}{*}{.008} \\
\hline & Non-Coaching & 20 & 24.98 & \\
\hline & Total & 40 & & \\
\hline
\end{tabular}


Orem's Nurse Coaching Approach on Interdialytic Weight Gain Changes and Phlebitis in Chronic Kidney Disease Client with Hemodialysis

Table 5 showed in the initial IDWG in each group obtained $\mathrm{p}$ value 0.156 , meaning that there was no difference in IDWG average between coaching and non-coaching groups. Each group performed coaching and noncoaching treatment up to seven treatments. The seventh treatment resulted in $\mathrm{p}$ value 0.008 , meaning that there was an IDWG means difference between coaching and non-coaching group.

Table6. Percentage of Phlebitis coaching and noncoaching groups

\begin{tabular}{|c|c|c|c|c|c|c|c|c|}
\hline & \multicolumn{4}{|c|}{$\begin{array}{l}\text { Coaching Groups } \\
(\mathrm{N}=20)\end{array}$} & \multicolumn{4}{|c|}{$\begin{array}{l}\text { Non-Coaching } \\
\text { Groups }(\mathrm{N}=20)\end{array}$} \\
\hline & \multicolumn{2}{|c|}{ Phlebitis } & \multicolumn{2}{|c|}{\begin{tabular}{|l|} 
Non \\
Phlebitis
\end{tabular}} & \multicolumn{2}{|c|}{ Phlebitis } & \multicolumn{2}{|c|}{$\begin{array}{l}\text { Non } \\
\text { Phlebitis }\end{array}$} \\
\hline & \begin{tabular}{|l|l}
$\begin{array}{l}\text { Frequ } \\
\text { ency }\end{array}$ & 9 \\
\end{tabular} & $\%$ & $\begin{array}{l}\text { Frequ } \\
\text { ency }\end{array}$ & $\%$ & \begin{tabular}{|l|}
$\begin{array}{l}\text { Frequ } \\
\text { ency }\end{array}$ \\
\end{tabular} & $\%$ & $\begin{array}{l}\text { Frequ } \\
\text { ency }\end{array}$ & $\%$ \\
\hline 0 & \begin{tabular}{|l|l}
11 & 5 \\
\end{tabular} & 55 & 9 & 45 & 7 & 35 & 13 & 65 \\
\hline $1^{\text {st }}$ & 11 & 55 & 9 & 45 & 7 & 35 & 13 & 65 \\
\hline $2^{\text {nd }}$ & 11 & 55 & 9 & 45 & 7 & 35 & 13 & 65 \\
\hline $3^{\text {rd }}$ & 9 & 45 & 11 & 55 & 7 & 35 & 13 & 65 \\
\hline $4^{\text {th }}$ & 7 & 35 & 13 & 65 & 6 & 30 & 14 & 70 \\
\hline $5^{\text {th }}$ & 6 & 30 & 14 & 70 & 7 & 35 & 13 & 65 \\
\hline $6^{\text {th }}$ & 6 & 30 & 14 & 70 & 6 & 30 & 14 & 70 \\
\hline $7^{\text {th }}$ & 6 & 30 & 14 & 70 & 7 & 35 & 13 & 65 \\
\hline
\end{tabular}

Table 6 showed that the percentage of phlebitis group coaching before coaching treatment was $45 \%$ and after being treated until the seventh treatment the rate of phlebitis increased to $70 \%$. In the other hand, in the non-coaching treatment group the percentage of phlebitis incidence before being treated with noncoaching was $65 \%$, and in the seventh treatment, the percentage remained $65 \%$.

Table7. Friedman test on Phlebitis for coaching and non-coaching groups

\begin{tabular}{|l|c|c|c|c|}
\hline \multirow{2}{*}{} & \multicolumn{2}{|c|}{$\begin{array}{c}\text { Coaching Groups } \\
\text { (N=20) }\end{array}$} & \multicolumn{2}{c|}{$\begin{array}{c}\text { Non-Coaching } \\
\text { Groups }\end{array}$} \\
\cline { 2 - 5 } & $\begin{array}{c}\text { Mean }=20) \\
\text { Rank }\end{array}$ & P-value & $\begin{array}{c}\text { Mean } \\
\text { Rank }\end{array}$ & P-value \\
\hline $\begin{array}{l}\text { Initial } \\
\text { Phlebitis }\end{array}$ & 3.98 & & 4.45 & \\
\hline $\begin{array}{l}1^{\text {st }} \\
\text { Phlebitis }\end{array}$ & 3.98 & & 4.45 & \\
\hline $\begin{array}{l}2^{\text {nd }} \\
\text { Phlebitis }\end{array}$ & 3.98 & .000 & 4.45 & .947 \\
\hline $\begin{array}{l}3^{\text {rd }} \\
\text { Phlebitis }\end{array}$ & 4.38 & & 4.45 & \\
\hline $\begin{array}{l}4^{\text {th }} \\
\text { Phlebitis }\end{array}$ & 4.78 & & 4.65 & \\
\hline $\begin{array}{l}5^{\text {th }} \\
\text { Phlebitis }\end{array}$ & 4.98 & & 4.45 & \\
\hline
\end{tabular}

\begin{tabular}{|l|c|l|l|l|}
\hline $\begin{array}{l}6^{\text {th }} \\
\text { Phlebitis }\end{array}$ & 4.98 & & 4.65 & \\
\hline $7^{\text {th }}$ & 4.98 & & 4.45 & \\
Phlebitis & & & & \\
\hline
\end{tabular}

Table 7 showed Friedman's results of average phlebitis in the coaching group, and noncoaching group obtained $\mathrm{p}$ value 0.000 and 0.947 . So it can be concluded that there is an average relationship of the incidence of phlebitis before and after the seventh phlebitis in the coaching group and no connection of the incidence of phlebitis before and after seventh phlebitis in the non-coaching group.

Table8. Paired wise comparison Phlebitis on coaching groups

\begin{tabular}{|l|c|}
\hline & $P$-Value \\
\hline Initial Phlebitis vs First Phlebitis & 1.000 \\
\hline Initial Phlebitis vs Second Phlebitis & 1.000 \\
\hline Initial Phlebitis vs Third Phlebitis & .157 \\
\hline Initial Phlebitis vs Fourth Phlebitis & .046 \\
\hline Initial Phlebitis vs Fifth Phlebitis & .025 \\
\hline Initial Phlebitis vs Sixth Phlebitis & .025 \\
\hline Initial Phlebitis vs Seventh Phlebitis & .025 \\
\hline First Phlebitis vs Second Phlebitis & 1.000 \\
\hline First Phlebitis vs Third Phlebitis & .157 \\
\hline First Phlebitis vs Fourth Phlebitis & .046 \\
\hline First Phlebitis vs Fifth Phlebitis & .025 \\
\hline First Phlebitis vs Sixth Phlebitis & .025 \\
\hline First Phlebitis vs Seventh Phlebitis & .025 \\
\hline Second Phlebitis vs Third Phlebitis & .157 \\
\hline Second Phlebitis vs Fourth Phlebitis & .046 \\
\hline Second Phlebitis vs Fifth Phlebitis & .025 \\
\hline Second Phlebitis vs Sixth Phlebitis & .025 \\
\hline Second Phlebitis vs Seventh & .025 \\
Phlebitis & .157 \\
\hline Third Phlebitis vs Fourth Phlebitis & .083 \\
\hline Third Phlebitis vs Fifth Phlebitis & .083 \\
\hline Third Phlebitis vs Sixth Phlebitis & .083 \\
\hline Third Phlebitis vs Seventh Phlebitis & .317 \\
\hline Fourth Phlebitis vs Fifth Phlebitis & .317 \\
\hline Fourth Phlebitis vs Sixth Phlebitis & .317 \\
\hline Fourth Phlebitis vs Seventh Phlebitis & 1.000 \\
\hline Fifth Phlebitis vs Sixth Phlebitis & 1.000 \\
\hline Fifth Phlebitis v Seventh Phlebitis & 1.000 \\
\hline Sixth Phlebitis vs Seventh Phlebitis & \\
\hline
\end{tabular}

In initial phlebitis vs. first phlebitis obtained $p$ value 1.000. This phlebitis was then observed until the seventh coaching treatment. However, the initial phlebitis vs. the seventh phlebitis obtained p-value of 0.025 . Thus, it is concluded that there is a significant difference from before treatment to the treatment of seventh coaching in this group. 
Orem's Nurse Coaching Approach on Interdialytic Weight Gain Changes and Phlebitis in Chronic Kidney Disease Client with Hemodialysis

Table9. Mann Whitney test on Phlebitis between Coaching and Non-Coaching groups

\begin{tabular}{|c|c|c|c|c|}
\hline & Groups & $\mathrm{N}$ & $\begin{array}{l}\text { Mean } \\
\text { Rank }\end{array}$ & $\begin{array}{c}P \text { - } \\
\text { value }\end{array}$ \\
\hline \multirow{2}{*}{$\begin{array}{l}\text { Initial } \\
\text { phlebitis } \\
\text { indication }\end{array}$} & Coaching & 20 & 18.50 & \multirow[t]{2}{*}{.209} \\
\hline & $\begin{array}{l}\text { Non- } \\
\text { coaching }\end{array}$ & 20 & 22.50 & \\
\hline \multirow{2}{*}{$\begin{array}{l}\text { First } \\
\text { phlebitis } \\
\text { indication }\end{array}$} & Coaching & 20 & 18.50 & \multirow[t]{2}{*}{.209} \\
\hline & $\begin{array}{l}\text { Non- } \\
\text { coaching }\end{array}$ & 20 & 22.50 & \\
\hline \multirow{2}{*}{$\begin{array}{l}\text { Second } \\
\text { phlebitis } \\
\text { indication }\end{array}$} & Coaching & 20 & 18.50 & \multirow[t]{2}{*}{.209} \\
\hline & $\begin{array}{l}\text { Non- } \\
\text { coaching }\end{array}$ & 20 & 22.50 & \\
\hline \multirow{2}{*}{$\begin{array}{l}\text { Third } \\
\text { phlebitis } \\
\text { indication }\end{array}$} & Coaching & 20 & 19.50 & \multirow[t]{2}{*}{.524} \\
\hline & $\begin{array}{l}\text { Non- } \\
\text { coaching }\end{array}$ & 20 & 21.50 & \\
\hline \multirow{2}{*}{$\begin{array}{l}\text { Fourth } \\
\text { phlebitis } \\
\text { indication }\end{array}$} & Coaching & 20 & 20.00 & \multirow[t]{2}{*}{.739} \\
\hline & $\begin{array}{l}\text { Non- } \\
\text { coaching }\end{array}$ & 20 & 21.00 & \\
\hline \multirow{2}{*}{$\begin{array}{l}\text { Fifth } \\
\text { phlebitis } \\
\text { indication }\end{array}$} & Coaching & 20 & 21.00 & \multirow[t]{2}{*}{.739} \\
\hline & $\begin{array}{l}\text { Non- } \\
\text { coaching }\end{array}$ & 20 & 20.00 & \\
\hline \multirow{2}{*}{$\begin{array}{l}\text { Sixth } \\
\text { phlebitis } \\
\text { indication }\end{array}$} & Coaching & 20 & 20.50 & \multirow[t]{2}{*}{1.000} \\
\hline & $\begin{array}{l}\text { Non- } \\
\text { coaching }\end{array}$ & 20 & 20.50 & \\
\hline \multirow{2}{*}{$\begin{array}{l}\text { Seventh } \\
\text { phlebitis } \\
\text { indication }\end{array}$} & Coaching & 20 & 21.00 & \multirow[t]{2}{*}{.739} \\
\hline & $\begin{array}{l}\text { Non- } \\
\text { coaching }\end{array}$ & 20 & 20.00 & \\
\hline
\end{tabular}

Early phlebitis indication between coaching group and non-coaching group was demonstrated with p-value of 0.209 meaning there was no difference of first signs of phlebitis between coaching group and noncoaching group. Table 9 also showed the seventh signs of phlebitis in each cluster obtained $\mathrm{p}$ value 0.739 . Thus, it is concluded that there is no difference in phlebitis between coaching and non-coaching groups in the seven treatments.

\subsection{Discussion}

The results of this study indicate that the majority of respondents are adult and elder adult. These results are consistent with the results of previous studies (Restu \& Woro, 2015; Pieter \& Ivy, 2015). The results of this study further indicate that between men and women sufferer are balanced different from previous studies conducted by Pieter and Ivy (2015) who found that the incidence of chronic renal failure is more common in women. This phenomenon may occur because the respondents in this study were obese patients, diabetes mellitus, and hypertension in which the number of male and female patients are balanced.
In this study, all respondents in the coaching group and the non-coaching group suffered from CKD stage V. This was by Saniyaty (2015) where the sample used for the study of hemodialysis patients to determine the level of uric and creatinine in pre and post-Hemodialisa is a staging $\mathrm{V}$ patient. Therefore in stage $\mathrm{V}$, CKD patients require hemodialysis therapy (Fauci et al., 2012).

In this study, IDWG results obtained in the first IDWG coaching group vs the seventh IDWG received $p$ value 0.239 indicating there is no change in the first IDWG vs. the seventh IDWG. But in the sixth IDWG comparison vs the seventh IDWG produced p-value 0.014 . So it is concluded there is a difference of the sixth IDWG vs. IDWG seventh. In this study, IDWG in coaching group is more effective than noncoaching group.

Coaching is a process of coaching to become partnership designed to help clients meet what is desired in their personal and professional lives to improve their performance and improve their quality of life. Trainers provide support to improve clients' skills, resources, and creativity. So in the application, patients have required the self-control for compliance and discipline.

According to Arditawati (2013), obedience is disciplined and disciplined behavior. Someone is said to obey the hemodialysis diet when consuming the food that has been determined by the amount that has been set and willing to carry out what is recommended.

In initial phlebitis vs. first phlebitis obtained $\mathrm{p}$ value 1.000. This phlebitis was observed until the seventh coaching treatment. But, phlebitis before vs. seventh phlebitis received $p$ value of 0.025 . This way, it is concluded that there is a significant difference from before treatment to the treatment of seventh coaching in this group.

\section{CONCLUSION}

Comparison of the first IDWG vs the seventh IDWG in coaching group produced $\mathrm{p}$ - value = 0.239 indicating there was no change in the first IDWG vs. the seventh IDWG. But on the sixth IDWG comparison vs the seventh IDWG $\mathrm{p}$-value generated was 0.014 denoting there is a difference of the sixth IDWG vs. the seventh IDWG. Initial phlebitis vs the first phlebitis produced $p$ - value $=1.000$ where as in initial phlebitis vs the seventh phlebitis, the $\mathrm{p}$ - value was 0.025 confirming there is significant 
Orem's Nurse Coaching Approach on Interdialytic Weight Gain Changes and Phlebitis in Chronic Kidney Disease Client with Hemodialysis

difference from before treatment until treatment of the seventh coaching in this group.

From this result, Orem's Learning Model with a coaching approach on renal failure clients with hemodialysis is expected to be a goal to explore hidden potentials in improving patient and family compliance with fluid intake restriction and quality of life for patients with chronic renal failure with hemodialysis.

\section{REFERENCES}

[1] Alligood, M. (2004). Self- Care Theory in Nursing: Selected Papers of Dorothea Orem. Journal of Advanced Nursing, 45(5), 549-549.

[2] Arditawati, S. (2013). Pengaruh Pendidikan Kesehatan Terhadap Kepatuhan Pasien CKD Untuk Mempertahankan Kualitas Hidup di RSUD Pandanarang Boyolali. Surakarta: Universitas Muhammadiyah Surakarta.

[3] Fauci AS, Kasper DL, Longo D, Braunwald E, Hauser S, Jameson JL, dkk. 2012. Harrison's principles of internal medicine. Edisi ke-18. USA: The McGraw-Hill Companies.

[4] Levey, A.S., Coresh, J., Balk, E., Kaustz, A.T., \& Levin, A. (2003). National kidney foundation practice guidelines for chronic kidney disease: evaluasi, klasifikasi, and stratification. Ann Interm Med. 139. 137-147
[5] Muttaqin, A., \& Sari, K. (2011). Asuhan keperawatan gangguan sistem perkemihan. Jakarta: Salemba Medika

[6] Pace, R.C. (2007). Fluid management in patient on hemodialysis. Nephrology Nursing Journal. September-Oktober 2007. 34(5). 557559

[7] Pieter Henfkesa, Ivy Violan Lawalata (2014). Faktor Risiko Penyakit Gagal Ginjal Kronik. Molluca Medica, Volume 8, Nomor 1, Oktober 2015, $\mathrm{Hml} 72-81$

[8] Riyanto, W. (2011). Hubungan antara penambahan berat badan di antara dua waktu hemodialisis (Interdialysis Weight Gain = IDWG) terhadap kualitas hidup pasien penyakit ginjal kronik yang menjalani terapi hemodialisis di unit hemodialisa IP2K RS Fatmawati Jakarta. Jakarta: FIK UI

[9] Restu Pranandari, Woro Supadmi (2015). Faktor Risiko Gagal Ginjal Kronik Di Unit Hemodialisis Rsud Wates Kulon Progo. Majalah Farmaseutik, Vol 11 No 2 Tahun 2015

[10] Saniyaty, Nisa. (2015). Hubungan Antara Karakteristik Pasien Gagal Ginjal Kronik Terhadap Kadar Ureum dan Kreatinin pada Pre dan Post Hemodialisis. Bandung: Universitas Islam Bandung.

[11] Suharyanto, T., \& Madjid, A. (2009). Asuhan Keperawatan pada Klien dengan Gangguan Sistem Perkemihan. Jakarta: TIM.

Citation: Shobirun, Supriyadi, Elisa, Sri Utami Dwiningsih, Heru Supriyatno, Sawab. Orem's Nurse Coaching Approach on Interdialytic Weight Gain Changes and Phlebitis in Chronic Kidney Disease Client with Hemodialysis. ARC Journal of Nursing and Healthcare. 2017; 3(2):9-14. doi: dx.doi.org/ 10.20431/24554324.0302003.

Copyright: () 2017 Authors. This is an open-access article distributed under the terms of the Creative Commons Attribution License, which permits unrestricted use, distribution, and reproduction in any medium, provided the original author and source are credited. 
Orem's Nurse Coaching Approach on Interdialytic Weight Gain Changes and Phlebitis in Chronic Kidney Disease Client with Hemodialysis 